\title{
Ексергетична ефективність заміни холодильного агента R410A на R32 у split-кондиціонері
}

\author{
В .Й. Лабай
}

Національний університет «Львівська політехніка», вул. Ст. Бандери, 12, Львів, 79013, Україна

$\triangle$ e-mail: wlabay@i.ua

\begin{abstract}
Розроблено математичну модель ексергетичного методу аналізу роботи одноступеневих хладонових холодильних машин, які використовують в місцевих автономних кондиціонерах. Визначено ексергетичний ККД та втрати ексергії у окремих елементах split-кондиціонера з номінальною холодопродуктивністю 2800 Bm фірми «Daikin» для стандартних зовнішніх температурних умов на холодильних агентах R410A ma R32. Bстановлено, що заміна холодильного агента R410A на R32 nідвищить ексергетичну ефективність splitкондиціонера на 3,4\%. Втрати ексергї, встановлені у всіх елементах холодильної машини split-кондиціонера, свідчать які елементи split-кондиціонера треба вдосконалювати для зменшення втрат ексергії в них $i$ загального підвищення ексергетичного ККД.
\end{abstract}

Ключові слова: Ексергетичний баланс; Split-кондиціонер; Ексергетична ефективність; Холодильний агент; Втрати ексергї

(C) The Author(s) 2017. This article is an open access publication

This work is licensed under the Creative Commons Attribution 4.0 International License (CC BY) http://creativecommons.org/licenses/by/4.0/

\section{1. Вступ}

Сьогодні для України проблема заощадження енергетичних ресурсів особливо актуальна в умовах ринкової економіки за обмежених ресурсів основних енергоносіїв - нафти та газу.

Тому в останні десятиріччя за кордоном з метою заощадження енергетичних ресурсів ведуться фундаментальні дослідження діяльності ряду галузей, виробництв i технологій із позицій ексергетичної методології [1-3]. Ця методологія була обгрунтована у роботах Р.К. Клаузіуса, Дж.В. Гіббса, Ж. Гюі, А. Стодоли, Я. Шаргута та Р. Петели. Величина, що визначає придатність до дії (працездатність) ресурсів речовини та енергії, була названа ексергією, а функції, що визначають іï значення, - ексергетичними. Ексергія визначає перетворюваність, придатність енергії для технічного використання в будь-яких заданих умовах. Отже, ексергія $\epsilon$ деякою універсальною мірою енергетичних ресурсів. А ексергетичний баланс, на підставі якого встановлюється масштаб використання енергетичних ресурсів, вказує на можливість підвищення коефіцієнта корисної дії (ККД) процесу.

Нині вартісні оцінки не можуть служити єдиною мірою ефективності енергетичного обладнання, які переробляють енергоресурси. Ексергія є фізичним, а не економічним критерієм і визначає незалежність цього параметра від кон'юнктурних коливань цін. В той самий час вартісні показники не дозволяють здійснити довгострокове прогнозування. Визначати мінімум необхідно не грошовими витратами, а витратами ексергії на одиницю виданої теплоти. Непридатність тільки грошових критеріїв очевидна.
У деяких провідних європейських країнах і в США ексергетичний аналіз запровадили як обов'язкову складову розроблюваних проектів, а також планів модернізації виробництв.

Ексергія системи у даному стані вимірюється кількістю перетворюваної енергії, яка може бути отримана від системи завдяки іiі зворотному переходу 3 даного стану в стан рівноваги 3 навколишнім середовищем.

Ексергетичний аналіз дозволяє встановити максимальні термодинамічні можливості системи, визначити втрати ексергії в ній та обгрунтувати рекомендації 3 вдосконалення окремих іiі елементів [1 6].

Сучасні місцеві автономні, зокрема splitкондиціонери, які використовують для створення відповідного мікроклімату у невеликих приміщеннях, досягли певного технічного вдосконалення. Енергетична ефективність холодильних машин цих split-кондиціонерів зумовлена параметрами як зовнішнього, так i внутрішнього їх температурних режимів роботи та видом холодильного агенту. Тому для подальшого підвищення ефективності роботи холодильних машин split-кондиціонерів потрібний детальний аналіз їхнього функціонування.

Отже, зменшення затрат енергії, яка споживається split-кондиціонерами, диктує необхідність їх оптимізації, що найповніше може бути досягнуто на основі ексергетичного аналізу, який враховує не тільки кількість, але й якість затраченої енергії [1-6].

Для цього авторами розроблено математичну модель ексергетичного методу аналізу холодильних машин split-кондиціонерів, який $\epsilon$ методом 
термодинамічного дослідження холодильної машини як загалом, так і їі окремих частин, щоб отримати повну інформацію про процеси перетворення енергії, які мають місце в таких системах [4-6]. Результатом аналізу є знаходження ексергетичного ККД процесу загалом та втрат ексергії в окремих елементах технічної системи.

\section{2 Основна частина}

Метою цієї роботи є визначення ексергетичного ККД та втрат ексергії в окремих елементах splitкондиціонера фірми «Daikin», яка переходить 3 двокомпонентного холодильного агента R410A на однокомпонентний R32. Для цього потрібно встановити:

- ексергетичний ККД split-кондиціонера 3 номінальною холодопродуктивністю 2800 Вт фірми «Daikin» за стандартних зовнішніх температурних умов на холодильних агентах R410A та R32;

- втрати ексергії в окремих елементах splitкондиціонера фірми «Daikin» зі стандартною холодопродуктивністю 2800 Вт на холодильних агентах R410A та R32.

Це і було завданням досліджень.

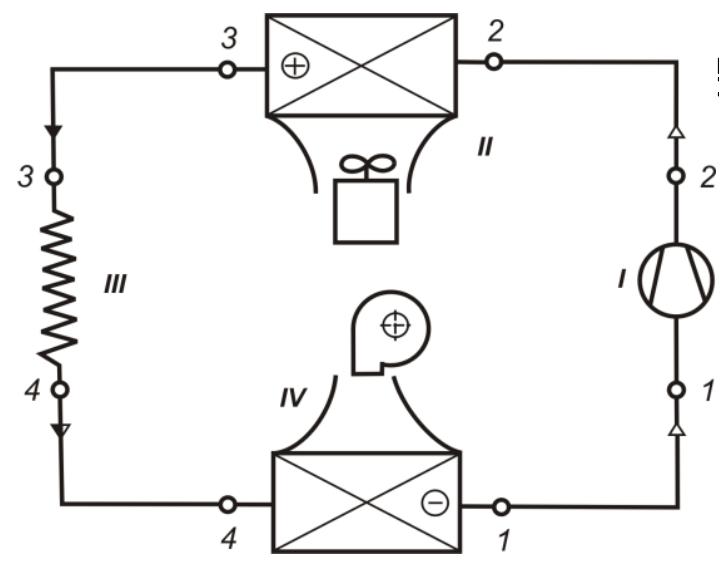

$a$

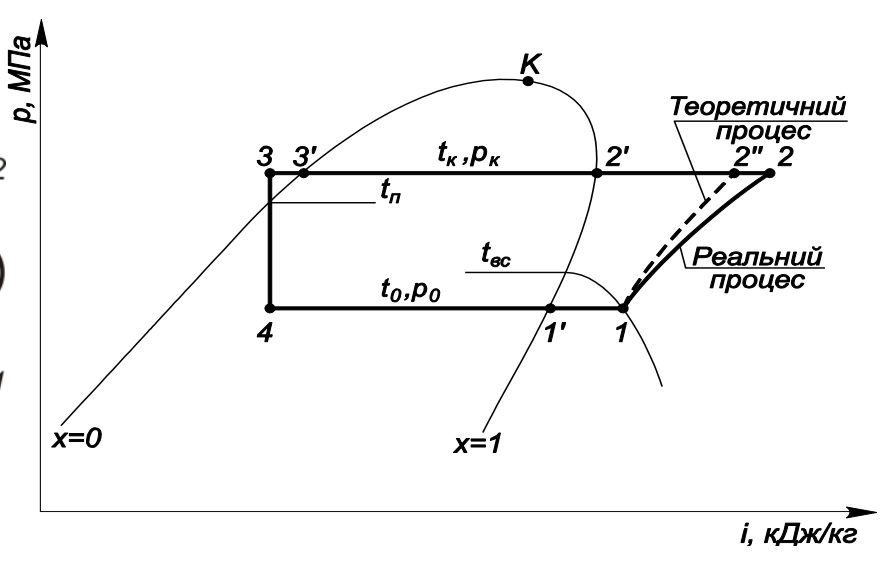

$\sigma$

I-компресор; II -конденсатор; III - капілярна трубка; IV-випарник

Рисунок 1 - Схема холодильної машини split-кондиціонера (a) та побудова процесів роботи на р,i-діаграмі (б):

Для розрахунку ексергетичного ККД та аналізу роботи холодильної машини split-кондиціонера необхідно мати такі вихідні дані:

- стандартну холодопродуктивність split-кондиціонера $Q_{\mathrm{x}}^{\mathrm{cT}}$;

- температуру внутрішнього повітря на вході $t_{C_{1}}=27^{\circ} \mathrm{C}$ у випарник і припливного на виході $t_{C_{2}}{ }^{3}$ нього;

- температуру зовнішнього повітря на вході $t_{H_{1}}=35^{\circ} \mathrm{C}$ і на виході $t_{H_{2}} 3$ конденсатора;

- термодинамічні властивості холодильних агентів - хладонів R410A та R32;

- схему холодильної установки (рисунок $1, a$ ).

Розрахувавши температури випаровування та конденсації за стандартних зовнішніх температурних умов для випарника, коли внутрішне повітря приміщення, яке охолоджується у випарнику splitкондиціонера, має початкову температуру $t_{C_{1}}=27^{\circ} \mathrm{C}$ i для конденсатора, коли зовнішнє повітря, яким охолоджується конденсатор split-кондиціонера, має початкову температуру $t_{H_{1}}=35^{\circ} \mathrm{C}$, а також температури всмоктування пари холодильного агента у компресор і переохолодження рідкого холодильного агента у конденсаторі, будували процес роботи холодильної машини без охолодження компресора в термодинамічній $p, i$-діаграмі (рисунок $1, \sigma)$. характерних точках схеми за діаграмою або за таблицями знаходили параметри холодильного агента $[7,8]$.

Питома внутрішня індикаторна робота компресора split-кондиціонера становить:

$$
l_{i}=i_{2}-i_{1}, \text { кДж/кг. }
$$

За термодинамічною $p, i$-діаграмою визначаємо витрати теплоти на одиницю витрати робочого холодильного агента в окремих апаратах холодильної машини split-кондиціонера.

Знаходимо холодильний коефіцієнт установки split-кондиціонера за формулою:

$$
\varepsilon=\frac{\eta_{\mathrm{eM}} q_{0}}{l_{i}}
$$

де $\eta_{\mathrm{eм}}$ - електромеханічний ККД компресора $\left(\eta_{\mathrm{eм}}=\right.$ $=0,9) ; q_{0}=i_{1}-i_{4}$, кДж/кг - питома витрата теплоти у випарнику на одиницю витрати холодильного агента.

Ексергетичний ККД холодильної машини splitкондиціонера знаходили за формулою:

$$
\eta_{\mathrm{e}}=E_{\mathrm{c}} \cdot \varepsilon
$$


де $E_{c}=\frac{T_{\text {н.с }}}{\bar{T}_{\mathrm{c}}}-1-$ питома витрата електричної енергії (ексергіï) в ідеальному циклі, віднесена до одиниці теплоти, підведеної до теплоприймальника (випарника) з середньою температурою $\bar{T}_{c}, \mathrm{~K} ; T_{\text {н.с }}-$ температура довкілля, К.

Значення ексергії холодильного агента в характерних точках процесу визначали за формулою:

$$
e=i-i_{\text {н.с }}-T_{\text {н.с }}\left(s-s_{\text {н.с }}\right), \text { кДж/кг, }
$$

де $i$ - значення питомої ентальпії холодильного агента в характерних точках процесу, кДж/кг; $i_{\text {н.с }}-$ значення питомої ентальпї холодильного агента в стані $T_{\text {н.c }}$, $p_{\text {н.с }}$ (температура і тиск навколишнього середовища), який знаходиться в рівновазі 3 навколишнім середовищем, кДж/кг; $s$ та $s_{\text {н.с }}-$ відповідні значення ентропії холодильного агента, кДж/(кг·К), які визначали за термодинамічними таблицями або діаграмами $[7,8]$.

Знаходимо питому кількість ексергії, яка вводиться в холодильну машину split-кондиціонера у вигляді електричної енергії, підведеної до електродвигуна компресора, за формулою:

$$
e_{\mathrm{Bx}}=\frac{N_{\mathrm{c} \Pi} \cdot 10^{-3}}{G}, \text { кДж/кг, }
$$

де $N_{\text {сп }}$ - споживана потужність електродвигуном компресора, Вт; $G=Q_{\mathrm{x}} \cdot 10^{-3} / q_{0} \quad-\quad$ кількість циркулюючого холодильного агента у контурі холодильної машини, кг/с.

Знаходимо втрати ексергії в окремих апаратах холодильної машини split-кондиціонера:

$$
d=e_{\text {поч }}-e_{\text {кін }}, \text { кДж/кг, }
$$

або у відсотках від ексергії, яка вводиться у холодильну машину:

$$
D=\frac{e_{\text {поч }}-e_{\text {кін }}}{e_{\mathrm{Bx}}} \cdot 100, \%,
$$

де $e_{\text {поч }} i e_{\text {кін }}-$ значення питомої ексергії холодильного агента у на початку i в кінці процесу в окремому апараті холодильної машини split-кондиціонера, кДж/кг.

Ексергетичний баланс для холодильної машини split-кондиціонера має такий вигляд:

$$
E_{\mathrm{Bx}}=E_{\text {вих }}+\sum_{i=1}^{n} D_{i}, \mathrm{BT},
$$

де $E_{\mathrm{Bx}}-$ ексергія приводу холодильної машини splitкондиціонера, яка витрачається на підтримання процесу, Вт; $E_{\text {вих }}$ приріст ексергії повітря у кондиціонованих приміщеннях, Вт; $\sum_{i=1}^{n} D_{i}-$ сума ексергетичних втрат холодильної машини splitкондиціонера, Вт.

Ексергетичний баланс даної холодильної машини split-кондиціонера складали на основі ii принципової схеми (рисунок $1, a$ ).

Вочевидь, досконалість холодильної машини splitкондиціонера та іiі елементів тим вища, чим вищий ексергетичний ККД, який також визначали 3 ексергетичного балансу, а саме [1-6]:

$$
\eta_{\mathrm{e}}=\frac{E_{\text {вих }}}{E_{\text {вх }}} .
$$

Розрахунок ексергетичного ККД холодильної машини split-кондиціонера створює умови для вирішення питання економії паливно-енергетичних ресурсів [1-6].

Отже, ексергетичний ККД холодильної машини split-кондиціонера обраховували також за формулою (9), в якій чисельник $є$ корисним ексергетичним ефектом, а знаменник - затратами ексергії.

Нами проведений розрахунок ексергетичного ККД одноступеневої холодильної машини split-кондиціонера фірми «Daikin» 3 номінальною холодопродуктивністю $Q_{\mathrm{x}}^{\text {ст }}=2800$ Вт за стандартних температурних умов на холодильних агентах R410A тa R32. Для розрахунку приймали:

- переохолодження рідкого холодильного агента у конденсаторі $\Delta t_{\text {переох }}=5^{\circ} \mathrm{C}$;

- перегрівання пари холодильного агента у випарнику $\Delta t_{\text {перегр }}=10^{\circ} \mathrm{C}$;

- кінцеву різницю температур у випарнику (внутрішнього повітря i киплячого холодильного агента) $\Delta t_{\text {вип }}=2,8^{\circ} \mathrm{C}$;

- кінцеву різницю температур у конденсаторі (зовнішнього повітря i холодильного агента, який конденсується) $\Delta t_{\mathrm{\kappa}}=4,2^{\circ} \mathrm{C}$.

Для проведення розрахунків на комп'ютерній математичній моделі $p, i$-діаграма хладонів $\mathrm{R} 410 \mathrm{~A}$ та R32 у діапазоні температур $0 . .50{ }^{\circ} \mathrm{C}$ використали у вигляді аналітичних залежностей $p=f(t), i=\varphi(t), s=$ $=\psi(t)$.

Результати розрахунку зводимо у таблицю 1.

Таблиця 1 - Результати розрахунку ексергетичного ККД та втрат ексергї в елементах split-кондиціонера 3 номінальною холодопродуктивністю 2800 Вт фірми «Daikin»

\begin{tabular}{|l|c|c|c|c|c|}
\hline \multirow{2}{*}{$\begin{array}{c}\text { Холодильний } \\
\text { агент }\end{array}$} & \multicolumn{3}{|c|}{ Втрати ексергії в елементах split-кондиціонера, \% } & \multirow{2}{*}{$\begin{array}{c}\text { Ексергетичний ккд } \\
\eta_{\mathrm{e}}\end{array}$} \\
\cline { 2 - 5 } & $D_{\text {компр }}$ & $D_{\text {к }}$ & $D_{\text {др }}$ & $D_{\text {вип }}^{\text {н.т }}$ & 23,4 \\
\hline $\mathrm{R} 410 \mathrm{~A}$ & 26,9 & 20,4 & 10,7 & 18,5 & 24,2 \\
\hline $\mathrm{R} 32$ & 27,1 & 21,5 & 4,9 & 22,2 & \\
\hline
\end{tabular}




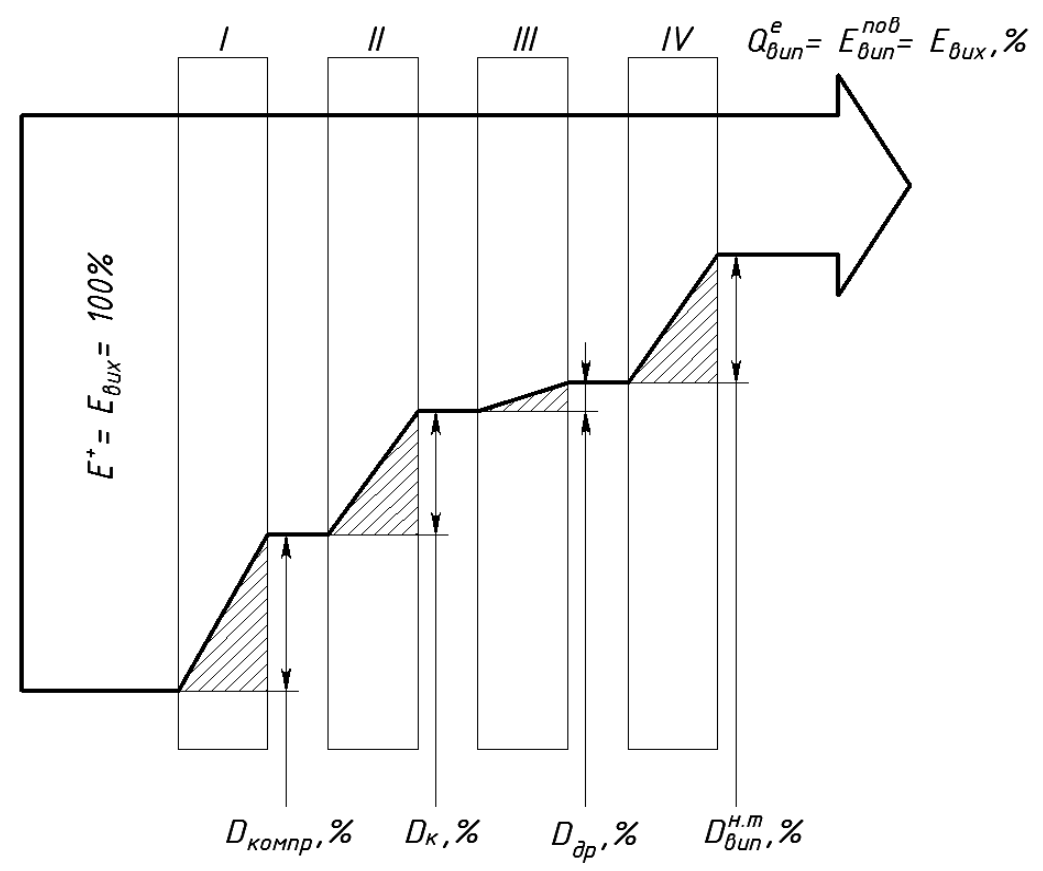

Рисунок 2 - Ексергетична діаграма потоків холодильної матини split-кондиціонера:

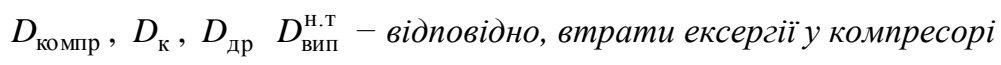

конденсаторі, капілярній трубиі та у випарнику

Зростання ексергетичного ККД завдяки переходу 3 холодильного агента R410A на R32:

$$
\Delta_{R 32}=\frac{24,2-23,4}{23,4} \cdot 100=3,4 \% .
$$

За результатами розрахунку будуємо ексергетичну діаграму потоків холодильної машини splitкондиціонера (рисунок 2).

\section{3 Висновки}

Розроблено математичну модель ексергетичного аналізу одноступеневих холодильних машин splitкондиціонерів для різних холодильних агентів. Виконано ексергетичний аналіз холодильної машини split-кондиціонера фірми «Daikin» зі стандартною номінальною холодопродуктивністю 2800 Вт на холодильних агентах R410A та R32. Показано, що перехід 3 холодильного агента R410A на R32 дасть можливість підвищити ексергетичний ККД за стандартного температурного режиму роботи на $3,4 \%$. Разом 3 тим використання однокомпонентного холодильного агента є раціональнішим для тривалої експлуатації split-кондиціонера. Отже, подальшим завданням дослідження повинен бути пошук однокомпонентних холодильних агентів, які дадуть можливість отримати ще вищий ексергетичний ККД, а значить кращі експлуатаційні характеристики splitкондиціонера. Отримані втрати ексергї у всіх елементах холодильної машини split-кондиціонера свідчать які елементи split-кондиціонера треба вдосконалювати для зменшення втрат ексергії в них і загального підвищення ексергетичного ККД.

\section{Література}

1. Соколов Е.Я. Энергетические основы трансформации тепла и процессов охлаждения / Е.Я. Соколов, В.М. Бродянский. - М.: Энергоиздат, 1981. $320 \mathrm{c}$.

2. Шаргут Я. Эксергия / Я. Шаргут, Р. Петела. - М.: Энергия, 1968. - 280 с.

3. Бродянский В.М. Эксергетический метод термодинамического анализа / В.М. Бродянский. - М.: Энергия, 1973. - 296 с.

4. Лабай В.Й. Залежність температурного режиму split-кондиціонерів від їх продуктивності за повітрям на випарнику і конденсаторі / В.Й. Лабай, О.В. Омельчук // Вісник Нац. унів. «Львівська політехніка». - 2006. № 561: Теплоенергетика. Інженерія довкілля. Автоматизація. - С. 20-25.

5. Лабай В.Й. Енергоощадні співвідношення між витратами повітря на випарнику і конденсаторі splitкондиціонерів / В.Й. Лабай, Я.М. Ханик // Науковотехнічний журнал «Холодильна техніка і технологія». Одеса: ОДАХ, 2008. - № 6 (116). - С. 28-31.

6. Лабай В.Й. Приведення роботи холодильних машин split-кондиціонерів до однакового внутрішнього температурного режиму / В.Й. Лабай, Й.С. Мисак // Науково-технічний журнал «Холодильна техніка і технологія». - Одеса: ОДАХ, 2010. - № 4 (126). - С. 1922.

7. Jakobsen A., Rassmussen B.-D., Skovrup M.-J., Andersen S.-E. CoolPack - a collection of simulation tools for refrigeration - Tutorial - Version 1.46. - Department of Energy Engineering Technical University of Denmark, 2001.

8. Daikin Catalog Split 2017.

Отримана в редакції 17.11.2017, прийнята до друку 08.12.2017 


\title{
Exergetic Efficiency of the Replacement Refrigeration Agent against R410A to R32 in the Air Split-Conditioner
}

\author{
V. Y. Labay ${ }^{\bowtie}$ O. M. Dovbush, V. Y. Yaroslav, O. V. Omelchuk \\ Lviv Polytechnic National University, 12 St. Bandery str., Lviv, 79013, Ukraine \\ $\triangle$ e-mail: wlabay@i.ua
}

\begin{abstract}
In modern technologies of energy transformation, namely in air split-conditioner, important places are occupied by equipment and processes, the objective estimation of value of its energy perfection can be defined only on the basis of analysis of its exergy effectiveness. Innovation mathematical research model of exergetic method of analysis of work of one-step freon refrigeration machines, that use in the local autonomous air conditioners, created by the authors, was used, which gave opportunity to make computer estimation of its energy effectiveness by the virtue of exergetic outputinput ratio (OIR) depending on different factors, which have influence on its work. Exergetic OIR and losses of exergy is certain in the separate elements of air split-conditioner with nominal cooling capacity $2800 \mathrm{~W}$ of firm "Daikin" for standart external temperature conditions on the refrigeration agents R410A and R32. It is set, that substituting of refrigeration agent $R 410 \mathrm{~A}$ by $R 32$ will promote exergetic efficiency of the air split-conditioner on the 3,4\%. Losses of exergy, install in all elements refrigeration machine of the air split-conditioner, what elements of air split-conditioner testify it is necessary to perfect for reduction of losses to the exergy in them and general increase of exergetic OIR.
\end{abstract}

Keywords: Exergetic balance; Air conditioner; Exergetic efficiency; Refrigeration agent; Losses of exergy

\section{References}

1. Sokolov E.Ia. 1981. Energeticheskie osnovy transformatsii tepla i protsessov okhlazhdeniia / E.Ia. Sokolov, V.M. Brodianskii. - Moskva: Energoizdat. - 320 (in Russian).

2. Shargut Ia. 1968. Eksergiia / Ia. Shargut, R. Petela. Moskva: Energiia. - 280 (in Russian).

3. Brodianskii V.M. 1973. Eksergeticheskii metod termodinamicheskogo analiza / V.M. Brodianskii. Moskva: Energiia. - 296 (in Russian).

4. Labai V.I. 2006. Zalezhnist temperaturnogo rezhymu split-kondytsioneriv vid ich produktyvnosti za povitriam na vyparnyku i kondensatori / V.I. Labai, O.V. Omelchuk // Visnyk Nats. univ. «Lvivska politechnika». - № 561: Teploenergetyka. Inzheneriia dovkillia. Avtomatyzatsiia. S. 20-25 (in Ukrainian).

5. Labai V.I. 2008. Energooshchadni spivvidnoshennia mizh vytratamy povitria na vyparnyku i kondensatori split- kondytsioneriv / V.I. Labai, Ia.M. Khanyk // Naukovotekhnichnyi zhurnal «Kholodylna tekhnika i tekhnologiia». - Odesa: ODAKH. - № 6 (116). - S. 28-31 (in Ukrainian).

6. Labai V.I. 2010. Pryvedennia roboty kholodylnykh mashyn split-kondytsioneriv do odnakovogo vnutrishniogo temperaturnogo rezhymu / V.I. Labai, I.S. Mysak // Naukovo-tekhnichnyi zhurnal «Kholodylna tekhnika i tekhnologiia» - Odesa: ODAKH. - № 4 (126). - S. 19-22 (in Ukrainian).

7. Jakobsen A., Rassmussen B.-D., Skovrup M.-J., Andersen S.-E. CoolPack - a collection of simulation tools for refrigeration - Tutorial - Version 1.46. - Department of Energy Engineering Technical University of Denmark, 2001 (in English).

8. Daikin Catalog Split 2017 (in Russian). 